\title{
Is it safer behind the gates? Crime and gated communities in South Africa
}

\author{
Gregory D. Breetzke ${ }^{1}$, Karina Landman ${ }^{2}$ and Ellen G. Cohn ${ }^{3}$ \\ ${ }^{1}$ College of Science, Department of Geography, University of Canterbury, Private Bag 4800, Christchurch, \\ 8140 , New Zealand \\ ${ }^{2}$ Department of Town and Regional Planning, University of Pretoria, Pretoria, Gauteng, 0001, South Africa \\ ${ }^{3}$ Department of Criminal Justice, Florida International University, PCA 261A, Miami, FL 33199, USA
}

Gregory D. Breetzke

Email: gregory.breetzke@canterbury.ac.nz

Karina Landman (Corresponding author)

Email: karina.landman@up.ac.za

Ellen G. Cohn

Email: $\underline{\text { cohne@ fiu.edu }}$

\begin{abstract}
Gated communities have long been seen as a rational response to rising crime levels, yet very little is known about the extent to which residing in a gated community actually reduces an individuals' risk of criminal victimisation. In this study we use location quotients tocompare the extent of burglary in gated communities with burglary across the entire city of Tshwane, South Africa as well as compare burglary in gated communities with burglary occurring within a series of buffer intervals immediately surrounding these communities. Finally, we identify what physical characteristics of gated communities differentiate between high and low burglary in these enclaves. Prior to expectations we found that gated communities (and theirimmediate surrounding areas) are associated with increased levels of burglary. There are
\end{abstract}


however, a number ofphysical characteristics of gated communities which are associated with much lower burglary levels. The implications of our work from a crime prevention and development planning perspective are discussed.

Keywords: gated communities; crime; South Africa; location quotients

\section{Introduction}

South Africa has experienced a dramatic increase in crime since the transition to democracy in April 1994. After an initial "honeymoon period" (Berg andSchärf, 2004, p. 61) from 19941996 during which crime levels dropped and momentarily stabilised, crime levels have risen steadily, with a levelling off in 2000/01, a dip in 2001/02, and then a gradual rise again reaching a new peak in 2003/04 (Altbeker, 2005). Since then crime levels have stagnated somewhat but are nevertheless still high when compared internationally. For example, the current murder rate in South Africa is 37.3 murders per 100,000 people, nearly five times the global murder rate of 7.6 murders per 100,000. Staggeringly, over 220,000 people have been murdered in the country in the past decade alone (South African Police Services (SAPS), 2011).Violent crimes are of particular concern, with almost a third of all South Africa's recorded crime classified as violent (SAPS, 2011). These worrying trends have lead researchers in the past to label South Africa as a post-conflict society (Malan, 1996) and even question whether crime is a threat to national security (Hough, 2003). Naturally, large sectors of South Africa's population are fearful of crime. Attitudinal surveys conducted by the Human Science Research Council (HSRC) have revealed that approximately 34per cent of South Africans feel personally unsafe on most days; 71per cent are fearful of walking alone 
in their own residential areas after dark and 15per cent are fearful of walking alone during the day (HSRC, 2006). After murder, housebreaking was the type of crime which respondents were most afraid of in the areas where they lived (Mistry, 2004).

It has been claimed that the post-apartheid surge in crime is a natural occurrence in transitional societies. The quoted example is that of the collapse of the socialist system in central and Eastern Europe where a dramatic increase in the amount of crime followed and was affected by the extreme social change (Lévay, 2000). Similar claims have been made for the increase in crime levels in transitional societies throughout Latin America and the former Soviet Union (see Shaw, 2002; Pridemore, 2007). As change and the processes of democratisation proceed in societies undergoing transition, the instruments of social control in society are transformed (Shaw, 1997). In South Africa, two forms of internal social organisation dramatically altered during the period of transition. First, the struggle against an authoritarian state produced opposing forms of community cohesion and social control, which kept criminality in check during the years of apartheid. Post-apartheid, these forms of control have since broken down or greatly dissipated. Second, many social structures, such as the church, community groups, the extended family and neighbourhood, were weakened by the broad changes in society and as a consequence lost their reach into the community. This is a result of the disruptive nature of transitions coupled with the violence that often accompanies them. Old forms of social organisation no longer provide an attractive option for the increasingly militarised and vocal sectors of the society. It is this breakdown of social and state controls that can create an environment more conducive to crime particularly in diverse transitional societies (Shaw, 2000).

There are a number of responses that typically occur in countries in which residents feel threatened by crime. One response is the creation of vigilante organisations that attempt to enforce the law in communities by providing a form of social control over 
residents.Unsurprisingly, a vast number of vigilante groups have arisen in the period since democracy, especially in poorer communities (Shaw, 2000). Another popular response to crime and the fear of crime is the target hardening of individual properties or in some instances entire neighbourhoods. In terms of the former, target hardening mechanisms may include locks, burglar alarms, fences, walls, and burglar bars. In terms of the latter, this may include changing the physical and social attributes of entire neighbourhoods through the creation of gated communities. It may not therefore be surprising to learn that South Africa has experienced a significant increase in different types of gated communities since democracy (Landman and Schönteich, 2002). While there are few hard data concerning the exact number of gated communities in the country, it is estimated that there are over 26,000 such enclaves currently operational (AfriGIS, 2011). While it is generally accepted that crime prevention is the most prominent driver behind the establishment of gated communities, very little research has been done on the actual impact of these developments on crime reduction both in these communities and in the surrounding areas.

In this paper we attempt to fill this gapby determining the extent to which residing in a gated community actually reduces a residents' risk of burglary victimisation. We investigate the effectiveness of gatingon burglary both during the day and during the night since previous research has shown how burglars change their targeting strategies depending on whether it is day time or night time (see Coupe and Blake, 2006). Employing methods of analytical research, we determine whether the extent of burglary in gated communities is higher or lower than in the immediate surrounding areas, as well as compare the extent of burglary in gated communities with burglary across an entire city. As a geographical focus area, the region under consideration is the city of Tshwane ${ }^{(1)}$ located in the central Gauteng province of South Africa. Tshwane is the capital city of South Africa and has an estimated residential

\footnotetext{
${ }^{(1)}$ In this study we used the pre-2011 municipal boundary for Tshwane.This includes 371 neighbourhoods. In May 2011 the boundary for the city of Tshwane expanded to incorporate the Metsweding District Municipality in the east of the city.
} 
population of approximately two million people. In the following section we briefly outline the existing debate around gated communities and crime, as presented in both the international and South African literature. This is followed by an empirical analysis of burglary in and around gated communities in Tshwane. A discussion of the implications of our findings concludes.

\section{Crime in gated communities: the debate}

A number of factors have contributed to the widespread proliferation of gated communities around the world. Among the most prominent factors include the need for privacy, exclusivity, conveniency, and a growing desire on the part of residents to be segregated from other sectors of society (see Dillon, 1994; Low, 2001, Lynch, 2001; Marcuse, 1997; WilsonDoenges, 2000). The most common worldwide explanation however for the growth of these enclaves is crime (Bremner, 1999; Atkinson et al, 2004) and the concomitant fear of crime (Landman, 2000; LandmanandSchönteich, 2002). In the United States the growth of gated communities is seen as a direct housing response to crime and disorder (Blakely and Snyder, 1998). Fuelled by a media that constantly broadcasts images of violence and crime, people have become increasingly fearful and have withdrawn into these fortified enclaves that they perceive to be safer and more secure. Blakely and Snyder (1997, pages 1-2) observe that "the phenomenon of walled cities and gated communities is a dramatic manifestation of a new fortress mentality growing in America." While this mentality has historically been the preserve of the white upper-class, this trend is changing with an increasing number of gated communities now developing in upper middle- and middle-class neighbourhoods in the United States (Plaut, 2011). In fact, recent evidence indicates that up to 38per cent of residents of owner gated communities in the south and west of the United States belong to the middle class (Vesselinov, 2008). The search for security is also believed to be the main driver of demand for gated communities in the United Kingdom (Atkinson et al, 2004), Lebanon 
(GlaszeandAlkhayyal, 2002); Mexico (Sheinbaum, 2008; Giglia, 2008), Argentina (RoitmanandGiglio, 2010), Brazil (Caldeira, 2000), Indonesia (Leisch, 2000), China (Miao, 2010), Nigeria (Uduku, 2010), Australia (Lee and Herborn, 2003) and New Zealand (Dixon andLysner, 2004).

Similar to the studies mentioned above, the main reason cited for the growth of gated communities in all major urban centresin South Africa is also crime (Bremner, 1999; Vrodljak, 2002), particularly the perception that serious violent crime in South Africa is increasingly out of control (Durington, 2009). Gated communities are seen as a way to prevent crime and relieve the fear of crime in a country where "fear has been transposed to an aesthetic principle" (Lipman and Harris, 1999, p.732). The walls and gates so prevalent in gated communities in South Africa are thought by residents to prevent, or at least limit, intrusions associated with crime, drugs, vandalism, and a general disregard for public and private property. Other reasons for gated communities in South Africa are closely aligned with the search for safety and security, or serve to reinforce security; for example, the territorialisationof private and public property. One of the purposes of gated communities is that of defining territory; to be able to differentiate areas spatially, fortify them against crime and the fear thereof, and ensure a sense of privacy and community inside (Davis, 1992; Luymes, 1997; Wilson-Doenges, 2000). Mills (1991) indicates that an important feature of the concept of enclosure is the assumption that social cohesion and group identity are determined in the built environment by means of enclosed territories. In the face of dramatic demographic, economic and social changes occurring in South Africa, gated communities provide a location where residents can be isolated in their territory safe from the dangers and changes that exist on the outside.

Of course, the question remains as to whether residing in a gated community actually reduces a resident's risk of criminal victimisation. A cursory review of the literature reveals 
surprisingly little empirical research about the effects of gated communities on crime rates, and the displacement of crime.In the United States., the majority of mainstream commentators believe that gating has very little real impact on crime levels (see Newman, 1980; Blakely and Snyder, 1997). For example, in California Wilson-Doenges (2000) compared four communities (two gated and two non-gated) and found no significant difference in actual crime rates per capita between gated and non-gated communities in both high-income and low-income communities. Similarly, Blakely and Snyder (1997) examined case studies in various different neighbourhood contexts throughout the United States and found no conclusive evidence of permanent reductions in crime. They found that some 'security zones' (enclosed neighbourhoods) reported a reduction in crime after the streets have been closed. Others, however, reported only temporary reductions, and some reported no change at all. In another study Helsley and Strange (1999) found that gating always diverts crime to other communities but has an overall deterrent effect on crime as long as it does not impact legitimate employment opportunities, and that gating may actually increase the overall level of crime if it either affects employment opportunities or influences selection among multiple equilibrium crime rates. Other evidence, however, has found a significant reduction in certain types of crime after the erection of barricades in neighbourhoods (see Atlas and LeBlanc, 1994), while still other researchers have found that crimes such as burglary do drop in the first year of a neighbourhood becoming gated, but then rise back to the level of the areas outside shortly thereafter (see Fowler andMangione, 1986).

From a South African perspective there is little consensus among researchers as to the effectiveness of gated communities in preventing crime. Advocates of gated communities generally base their argument on the enhanced security measures inherent in gating (Coetzer, 2001), while detractors point to the lack of empirical evidence in South Africa showing the crime preventive effects of instigating these elaborate and often expensive safety and security 
measures (Naudé, 2003). Anecdotally, the closing off of neighbourhoods and public roads are thought to reduce some opportunistic or impulsive crimes such as theft and petty street crimes (pick-pocketing and snatch-and-grab crimes) but overall crime levels are thought to remain the same.

Most prior research investigating the impact that gating has on preventing crime has however relied on survey and/or interview data with gated and non-gated residents or law enforcement agencies tasked with policing these neighbourhoods. To our knowledge no study has undertaken a geospatial analysis of officially recorded and geocoded crime data in gated and non-gated neighbourhoods and determined the extent to which gating is effective in preventing crime. In the following section we use geographical information systems to empirically ascertain the extent to which burglary varies spatially throughout Tshwane. In doing so we are able to determine whether residing in a gated community reduces aindividuals' risk of burglary victimisation or whether it in fact heightens the risk of such offences. Burglary was selected as the type of crime to examine because it is an invasive act that increases individuals' feeling of personal safety and security. In addition, security from burglary is often considered one of the main motivating factors for residing in a gated community (see Blandyand Parsons, 2002).

\section{Data and methods employed}

Two sets of data were compiled for use in this study. First, residential burglary data were obtained from the Crime and Information Analysis Centre of the SAPS for the years 20042006. The information provided by the SAPS included the specific geographic location of each residential burglary ( $\mathrm{x}$ and $\mathrm{y}$ co-ordinate), and the date and time of day at which the burglary was committed. A total of 57,276 incidences of residential burglary were recorded in Tshwane over this three year period $(M$ per month $=1591) ; 24,090$ (42 per cent) 
incidences were committed during the day (07:00am - 18:59pm) and 33,186 (58 per cent) incidences were committed during the night (19:00pm - 06:59am). Second, a dataset containing the location of gated communities in Tshwane was obtained from the Council for Scientific and Industrial Research. Following Blakely and Snyder (1997), we define a gated community as any residential area that has restricted access such that normally public spaces have been privatised. There are two types of gated communities in South Africa: enclosed neighbourhoods and security villages. The former refers to existing neighbourhoods that have controlled access through gates or booms across existing roads. The latter refers to private developments where the entire area is developed by a (private) developer. These areas are physically walled or fenced off and usually have a security gate or controlled access point,either with or without a security guard. In total there were 88 gated communities in Tshwane at the end of the 2003 calendar year. Table 1 provides descriptive statistics of some of the physical characteristics of these 88 gated communities in Tshwane.

Table 1.Physical characteristics of gated communities in Tshwane $(n=88)$

\begin{tabular}{|c|c|c|c|c|}
\hline & Mean & Min & Max & SD \\
\hline Area $\left(\mathrm{km}^{2}\right)$ & 0.35 & 0.00 & 6.13 & 0.72 \\
\hline Road density $\left(\mathrm{m} / \mathrm{km}^{2}\right)$ & 11409.93 & 0.00 & 107091 & 11053.19 \\
\hline Distance to national road (m) & 1898.62 & 159.10 & 5055.43 & 1231.77 \\
\hline No of land parcels & 170.85 & 1 & 1156 & 223.63 \\
\hline No of access points & 3.23 & 1 & 17 & 2.54 \\
\hline
\end{tabular}

As is evident from table 1, the physical characteristics of the 88 gated communities in Tshwane vary considerably. The average gated community in Tshwane is 0.35 kilometres squared. Gated communities range in size from less than a kilometre squared to over six kilometres squared. Smaller communities are usually enclosed neighbourhoods where the end 
of a cul-de-sac has been boomed off enclosing one or two residences. Larger gated communities in Tshwane consist mostly of luxury security villages. These villages have most often been developed by private developers and typically contain retail shops, schools and other recreational amenities such as golf courses, and hiking trails. The road density measure is similar to the mean for the whole city (10602.34 metres per kilometre squared) while each gated community has on average 170 parcels of land. It is important to note that the number of land parcels does not necessarily equate to the number of residences in each community. A gated community could consist of an apartment complex or numerous stack simplexes that would occupy only one land parcel. While a better approximation of the number of residences within each gated community is desirable, many of the security villages in Tshwane are privately operated and gaining access to relevant data is difficult if not impossible. Not surprisingly, the distance from each gated community to the nearest national road is close $(M=1898.62 \mathrm{~m})$. As is outlined below, the majority of gated communities are located in the former whites-only neighbourhoods in Tshwane. The close distance from each gated community to a national road can be seentherefore as a consequence of apartheid-era urban design in which the former whites-only neighbourhoods were located in close proximity to all major transport networks while the black African townships were located distant and distinct from the white urban core. Each gated community has on average three access points.

Figure 1 provides the location of the 88 gated communities used in the analysis. Not surprisingly, the spatial distribution of these communities is skewed, with the vast majority of these developments occurring in the south-eastern regions of the city, which is characteristic of the former whites-only neighbourhoods in Tshwane. In terms of its spatial structure the city of Tshwane consists of formerly whites-onlyneighbourhoodsimmediately surrounding the central business district. The former apartheid-era townships lie on the periphery of the 
city and include Atteridgeville (black African) and Laudium (Indian) on the western edge; the townships of Eersterus (Coloured) and Mamelodi (black African) on the eastern edge; and an arc of late-apartheid black African townships on the border of the former Tswana homeland in the northern periphery of the city. These outlying townships include Ga-Rankuwa, Mabopane, Soshanguve, Winterveld and Temba. The pre-1994 urban structure has been largely retained post-apartheid except for the almost complete replacement of whites by black Africans in large parts of the inner city; the expansion of black African townships with informal housing; and the establishment of a few informal settlements such as Olievenhoutbos amidst previously whites-onlyneighbourhoods.

\section{Empirical analysis}

In order to compare the extent of burglary in gated communities relative to areas outside gated communities we used location quotients (LQs). A LQ provides a measure that indicates how different an individual unit of analysis is relative to the total area under investigation. In the context of this study, a LQ would show the extent to which burglary in gated communities depart from the overall proportion in the city. For example, if a neighbourhood in Tshwane has a LQ of 1, then that neighbourhood has exactly the same relative frequency of burglary as is found across the entire city. If a neighbourhood has a LQ of 0.5 then that neighbourhood has half the amount of burglaries as the overall city, and is perhaps a less risky neighbourhood in which to reside. Conversely, if a suburb has a LQ greater than 1, then burglary is over-represented in that neighbourhood indicating a relative concentration of burglary at that location. Being a relative measure and without dimension, LQs provide a more vivid measure of crime risk than for example the high and low indicators of crime rates. In criminological form, the LQ formula is expressed as follows: 


$$
\mathrm{LQCi}=(\mathrm{Cij} / \mathrm{Ai}) /(\Sigma \mathrm{Cij} / \Sigma \mathrm{Ai})
$$

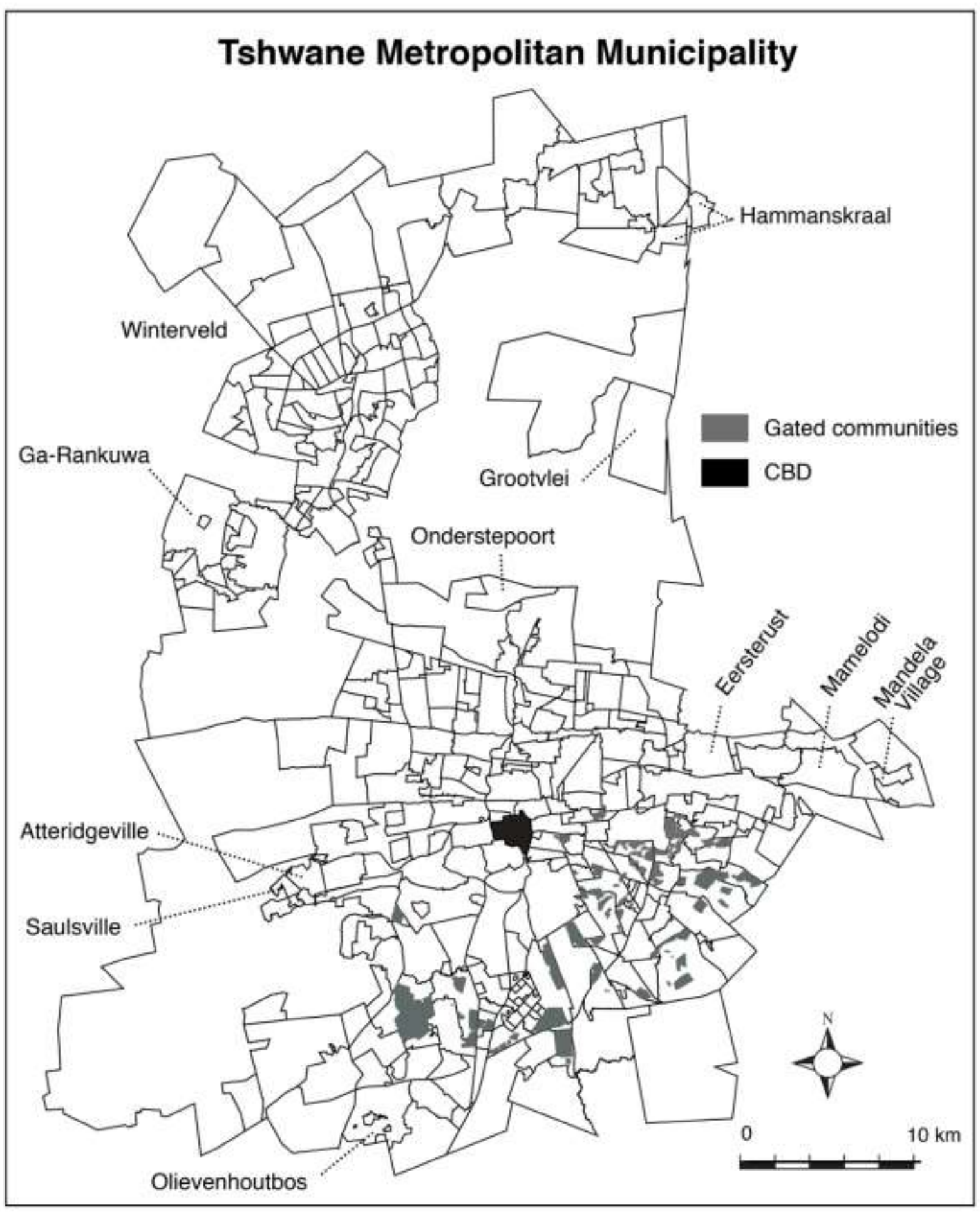

Figure 1.Location of the 88 gated communities in the city of Tshwane, South Africa 
Where:

$\mathrm{Cij}=$ crime frequency in neighbourhoodi

$\mathrm{Ai}=$ area measure like population at risk, total crime count in neighbourhoodi

$\Sigma \mathrm{Cij}=$ crime frequency in the whole area

$\Sigma \mathrm{Ai}=$ total area measure for the whole area

In the study, we calculated LQs for gated communities as well as for a series of buffer intervals immediately surrounding the gated communities. This was done in order to determine the impact of gated communities on burglary in the areas adjacent to them. It could be that burglars are deterred by the safety and security measures bounding the gated communities and instead burgle more easily accessible residences nearby (ie, crime displacement). Buffer intervals of 150 metres and 300 metres were constructed around each gated community because that distance is approximately the average length of a street block in Tshwane. The density of burglary in these three zones (ie, gated; $150 \mathrm{~m} ; 300 \mathrm{~m}$ ) are then compared to the density of burglary for the entire city of Tshwane and represented as a quotient.

Lastly, we tested the results obtained against the extent of burglary around a randomly selected set of 88 street intersections in the city. For each of these 88 randomly selected street intersections we constructed a 334metre buffer and calculated LQs for these areas. A buffer distance of roughly 334 metres was selected so that the total area covered by the random point selection was the same as the total area covered by the existing 88 gated communities in Tshwane (ie, $88 \pi(334 \mathrm{~m})^{2}=30.8$ kilometres squared (see table 1$)$ ). In this way we essentially 
have a 'control' gated community group for comparison. In comparing the LQ values in these random areas with values in the gated communities we mitigate the inherent problem of LQs in that they dilute the crime rate in comparison areas because they include places at which no crime could occur (for example, vacant land, parks, water bodies) (Groff and McCord, 2011; McCord andRatcliffe, 2009). Of course, it could be that the areas around some street intersections could offer little opportunity for burglaries too. But by definition the density of street intersections is higher in built up areas (Groff and McCord, 2011), thus a random selection is likely to include by chance intersections in high density areas and therefore provides a good comparison to gated communities which also tend to be located in more dense areas, with some exceptions. A comparison between the LQ values for these 88 random street intersection areas was then made with the LQs of the 88 existing gated communities. If the LQ for the density of burglary in gated communities is higher than for the 88 random areas then we can be more certain of the association between gated communities and burglary.

\section{Results}

The results of the LQ analysis are presented in table 2. Overall the density of burglary in gated communities was found to be over three and a half times that of Tshwane as a whole. Day time burglary was just under three and a half times that of the city whilst night time burglary was almost four times the density of Tshwane. These findings provide the first empirical clue that gated communities in Tshwane do not necessarily provide more security from crime either during the day or during the night. Areas immediately surrounding gated communities also have higher densities of burglaries than that of Tshwane, with both the 150 metres and 300 metres intervals exhibiting values higher than the overall city values. Interestingly there is no apparent drop off in burglary the further you go away from a gated 
community; in fact, there is a slight increase in burglary at the 300 metre buffer compared with the 150 metre buffer. Again, there are no discernable differences between values during the day and during the night at both buffer distances.

Next we sought to determine whether burglary in gated communities was significantly higher than elsewhere. We did this by comparing LQs in the 88 gated communities of Tshwane with burglary densities recorded in our gated 'control group' in Tshwane. The analysis of LQs around these 88 random areas is shown in the final record of table 2. Using ANOVA we found burglary densities in gated communities to be significantly higher than in the areas around the 88 randomly selected points $(p<0.001)$.

Table 2. Location quotients of burglary in and surrounding gated neighbourhoods $(n=88)$

\begin{tabular}{lccc}
\hline Buffer & All burglary & Day time burglary & Night time burglary \\
\hline Gated & 3.66 & 3.40 & 3.92 \\
150 metres & 2.93 & 2.90 & 2.95 \\
300 metres & 3.16 & 3.35 & 2.97 \\
Random points $(n=88)$ & 2.14 & 2.18 & 2.10 \\
\hline
\end{tabular}

We then investigated the concentration of burglary in gated communities. It could be that burglary is disproportionately distributed throughout the 88 gated communities resulting in some distortion in the relationship between gated communities and burglary. Results of this analysis (see table 3 ) revealed that 10per cent of gated communities $(n=9)$ accounted for half the burglaries reported over the three years in Tshwane. Subsequent analysis revealed that 20per cent of burglaries committed in gated communities in Tshwane occurred in just two gated communities - these two communities are the second and third biggest in the city. Incidentally, the largest gated community in Tshwane - which is more than five times bigger 
than the second biggest community - recorded only 2 per cent of the burglary incidences in gated communities in Tshwane. We also found some difference between day time and night time burglary, with a slightly lower number of gated communities $(n=7)$ accounting for 50per cent of day time burglary, although these differences are not substantial. Also evident in the results is the fact that burglary occurs within almost all gated communities. Only four gated communities in Tshwane had no reported burglary incidences from 2004-2006.The findings of this analysis suggest that whilst the association between burglary and gated communities in Tshwane is being predominantly driven by a few high burglary communities, burglary is still occurring frequently in almost all gated communities. There is also a suggestion that the physical characteristics of gated communities may play a role in whether or not burglary occurs there.

Table 3.Concentration of burglary in gated neighbourhoods

\section{Percentage of gated neighbourhoods accounting for \\ 50 per cent of burglary}

Percentage of gated neighbourhoods accounting for 100 per cent of burglary
All burglary
$10.23(n=9)$
95.45
Day time burglary
$7.95(n=7)$
84.10
Night time burglary
$11.36(n=10)$
89.77

Last, we sought to identify which physical characteristics of gated communities in Tshwane are associated with overall burglary risk. Based initially on simple Pearson correlations, larger gated communities were found to have higher incidences of burglary $(r=0.52$; $p<0.001)$. Gated communities with a high number of land parcels $(r=0.85 ; p<0.001)$ and more access points $(r=0.51 ; p<0.001)$ were also found to have higher incidences of burglary. The suggestion here is that where there are more entry and exit points, as well as more targets 
(houses) for burglars, the greater the burglary victimisation risk. The simple correlations with road density ( $r=-0.03 ; \mathrm{NS})$ and distance to national roads $(r=0.00 ; \mathrm{NS})$ were not significant. However, the simple Pearson correlations provide only one view of the relationship between burglary and the physical characteristics of gated communities. Greater accuracy can be obtained using partial correlation analysis since most of the physical characteristics of gated communities were found to be significantly related to each other (mean $r=0.25$ ). Partial correlations allow an estimate to be made to test the independent relation of each physical characteristic of gated communities to burglary. In each case, the effect of other physical characteristics is partialed from the simple correlation between a given physical characteristic and burglary in order to gain an alternative perspective of these relationships (see table 4).

Table 4. Partial correlations between burglary and the physical characteristics of gated neighbourhoods in Tshwane $(n=88)$

\begin{tabular}{lccc}
\hline & All burglary & Day burglary & Night burglary \\
\hline Area $\left(\mathrm{km}^{2}\right)$ & $-0.51 * * *$ & $-0.49 * * *$ & $-0.39 * * *$ \\
Road density $\left(\mathrm{m} / \mathrm{km}^{2}\right)$ & 0.00 & 0.03 & -0.01 \\
Distance to national road $(\mathrm{m})$ & -0.03 & -0.03 & -0.03 \\
No of land parcels & $0.85^{* * *}$ & $0.81 * * *$ & $0.79 * * *$ \\
No of access points & 0.00 & -0.00 & 0.01 \\
\hline Note: $* \mathrm{p}<05 * * \mathrm{p}<01 * * * \mathrm{p}<001$. & & &
\end{tabular}

The partial correlations of three of the five physical characteristics of gated communities (road density, distance to national roads, number of land parcels) with overall burglary did not differ much from the simple Pearson correlations provided earlier. However, there were notable shifts in the partial correlations for the area measure as well as the number of access 
points. As indicated in table 4, when all other physical characteristics are controlled for burglary is negatively correlated $-0.51(p<0.001)$ with land area, in contrast with the simple correlation of $0.52(p<0.001)$. Thus, although the simple correlation suggests that bigger gated communities have a higher risk of burglary, the partial correlation analysis indicates that when the effect of the other physical characteristics is controlled, burglary is significantly associated with smaller gated communities. This finding holds true both during the day and night time. Second, the simple correlation between the number of access points and burglary was $0.51(p<0.001)$, but the partial correlation was 0.00 (NS). Thus, when all the other physical characteristics are controlled, it appears as if the number of access points to a gated community has no association with burglary, both during the day and during the night time. Regardless of whether simple or partial correlations are utilised, the number of land parcels appears to be the most important factor of burglary risk in gated communities in Tshwane. Based on the partial correlation analysis the main findings suggest that smaller, and more dense (numbers of land parcels) gated communities are more vulnerable to burglary in Tshwane. The number of access points, the distance to the nearest national road, and the road density of a gated community do not appear to influence burglary risk after the other physical characteristics area partialed. The results of this descriptive and analytical analysis warrant further attention.

\section{Discussion}

Gated communities have long been seen as safe havens by residents (Kim, 2006; Vilalta, 2011; MohitandAbdulla, 2011). This is understandable given the vast number of physical safety and security mechanisms put in place in these communities. The primary aim of this research has been to investigate what effect gated communities have on aindividuals' risk of burglary victimisation. We were also interested in determining what physical characteristics 
of gated communities differentiate between high and low burglary in these communities. Not only did the results of our research show that gated neighbourhoods have a higher burglary density than Tshwane as a whole, but that they have a higher density of burglary than areas surrounding a random selection of 88 street intersections. Areas immediately surrounding gated neighbourhoods were also found to have higher burglary densities than the city as a whole, although there was no monotonic decrease in burglary the further you ventured away from the gated neighbourhood. In fact, burglary densities actually increased at the 150-300 metre buffer. These trends were consistent both during the day and during the night. These latter findings suggest that gated communities could displace crime to areas immediately adjacent tothem (as noted by Helsley and Strange, 1999), although burglary was also notably high in the gated communities themselves. Perhaps what is most staggering about the results is the magnitude of difference between burglary densities within and surrounding gated neighbourhoods and burglary in Tshwane as a whole. Areas in and around the vicinity of gated communities all have burglary densities up to four times that of Tshwane which suggests that gating does not deter criminal activity, but in factattracts it.

It is difficult to compare the results of this research with work conducted elsewhere given the contextual differences between South Africa and other countries. The alternate methodologies employed by other research of this nature also make comparisons problematic. These factors notwithstanding the results of our work are broadly similar to that of WilsonDoenges (2000) who found no significant differences between both perceived safety and actual crime rates between gated and non-gated communities in California. Similarly, Blakely and Snyder (1998) found no significant difference in crime rates between gated and nongated neighbourhoods in the same area of North America. More direct support for our findings has been found in Malaysia where Mohitand Abdulla (2011) found crime rates to be higher in gated communities than non-gated communities in two low-middle income housing 
communities. Their study relied however on the crime experiences and the perception of safety of residents in these communities and did not include any actual crime data. Lastly, in the United Kingdom Atkinson et al (2004) found little evidence to support the common conception that crime is reduced in gated communities and in fact warned that gated communities in the UK “...could even act as a focus for criminal activity" (page 3 ). Where our results differ greatly from this previous research is the extent to which crime is different in gated communities compared to non-gated communities. Our results indicate that gated communities experience much higher densities of burglary than do non-gated communities; sometimes up to four times as much. Essentially, gated communities were found to be significantly more prone to burglary than non-gated communities.

One possible explanation for this result might lie in the socio-demographics of the area where the majority of gated communities are located. As previously mentioned, the vast numbers of gated communities in Tshwane are located in the affluent former whites-only neighbourhoods in the south-eastern region of the city (figure 1). Previous research has found that burglars target affluent neighbourhoodsin Tshwane (see Breetzke, 2012) and it could be that when burglars target affluent neighbourhoodsin the city they target these areas regardless of whether the neighbourhood contains (or is part of) a gated community. In fact the results of this research suggest that within targeted neighbourhoods, gated communities are most sought after by burglars.

Another possible explanation for the increased density of burglary in gated communities in Tshwane could be the ease at which these crimes can be committed once offenders have gained access to gated properties. It may be that residents of gated communities perceive perimeter security as being sufficient for crime prevention and neglect to implement security measures at their own property or observe basic security principles. Residences are essentially lulled in to a false sense of security as a result and are less vigilant and alert to the 
threat of intruders. Access control strategies like high walls, palisade and electric fencing, patrol guards and key-pad entry systems can create false feelings of safety and security which can increase inhabitants' crime risk.

Of course the explanations provided above are based on the assumption that burglars come from outside gated communities to commit a burglary. Anecdotal evidence suggests that individuals residing within gated communities in South Africa are increasingly responsible for crimes committed inside these communities. Such individuals either act alone or facilitate the commission of the burglary by giving the offender access to the gated community (via a security code) and/or allow the offender to offload stolen property at their residence and allow them to retrieve the goods later on. Research investigating this phenomenon is lacking but the high incidences of burglaries in gated communities despite the formidable physical security measures in place would suggest that this kind of collaboration is possible. Lastly, there are a number of 'external' individuals that are allowed unlimited access to gated communities including domestic workers, municipal workers, telecommunication staff, construction workers, garden and repair and delivery services thus making the gated community far from secure from non-residents. While some communities limit the hours during which domestic workers and other employees may be in the community, or conduct random searches of domestic workers as they leave the community, these types of rules are not universal and are not always enforced (Durington, 2009). These combined factors make gated communities far from the reclusive, restricted fortified security enclave that they are purported to be.

Interestingly, physical characteristics related to the size of gated communities and the numbers of land parcels contained within them were related to burglary density. Of the various physical characteristics of gated communities that were investigated, only those two were found to be significant (either positively or negatively). The results indicated that 
smaller gated communities and gated communities with a larger number of land parcels are more vulnerable to burglary. This result is particularly interesting since these two characteristics are highly correlated with each other $(r=0.81 ; p<0.001)$ yet they exhibit contrasting values when they are partially correlated with burglary. From a planning perspective, the results of this research suggest that the size and numbers of land parcels in gated communities are the two most important construction considerations for planners when attempting to design out crime. The notion that that the environment can be designed to control human behaviour, or in this instance, curb criminal behaviour is a central tenet of defensible space theory (Newman, 1972). Newman's defensible space model argues that physical space can be structured in a way that fosters and reinforces a social structure that defends itself. Newman identified four key elements of defensible space: territoriality, natural surveillance, image, and milieu. The last element, the milieu, in a sense encapsulates the other three in that it involves placing an area within a larger community or physical space that contains territoriality, natural surveillance, and image, thus creating a defensible space that remains free of criminality activity (Paynichand Hill, 2010). In the context of this study, a gated community can be considered as one type of milieu that is inherently territorial, has more than adequate surveillance measures in place, and has an appearance that the neighbourhood is well cared for (image). As a result a gated community should, at least theoretically, be largely free of crime. Of course, the reality is often the antithesis, with the results of this research suggesting that in some instances the desire to commit a crime can supersede the various mechanisms put in place to prevent it. Alternatively, there are ways in which criminals can bypass the best laid environmental design plans in order to commit a criminal act.

Whilst the planning implications of these results are important, there is another sociopolitical issue to briefly consider. This is the issue of segregation. A lot has been written 
about the segregation effects of gated communities in South Africa (see JürgensandGnad, 2002; Lemanski, 2004; Landman, 2004) and it is beyond the scope of this paper to delve into this work. We do however find it relevant to make the point that whilst gatedcommunitiesmay be creating a new form of spatial segregation and social exclusion in South Africa they are also not accomplishing their primary goal, which is to prevent crime, or rather reduce the risk of criminal victimisation of residents. Whilst residents of gated communities in South Africa may perceive themselves at being at a reduced risk of criminal victimisation, this study has shown that they are, in fact, at a greater risk of becoming a victim of crime than those residing elsewhere. Whereas apartheid's urban spatiality was considered fundamental to maintaining social order; gated communities in the post-apartheid era should not be considered fundamental to preventing criminal disorder.

\section{Limitations}

The study's limitations do need to be considered. First, the study did not include illegal road closures, which include the unlawful fencing or walling off of a public space by means of gates or booms. Being illegal, these closuresare undocumented, which makes it difficult to know where they are located as well aswhen the relevant areas were closed. Second, we used official crime data to measure burglary. Using police data to measure crime has well-known limitations, particularly in South Africa (see Breetzke, 2006; Breetzkeand Horn, 2008). Despite this however previous research has shown that using official police data usually produces results consistent with victimization surveys (see Byrne and Sampson, 1986; McDowall andLoftin, 1992). In any event, official records from the SAPS represent the only official and spatially replete crime dataset available in the country. Third, the study examines the relationship between burglary and gated communities in one major metropolitan area in South Africa. The city of Tshwane has high and unique socio-spatial trends of burglary (see 
Breetzke, 2012). Thus, the findings are not necessarily generalizable to gated communities in other countries or even to gated communities in other South African cities. It could be that gated communities in contexts outside South Africa provide residents with greater protection from burglars than was shown in this study. Fourth, we grouped the various types of gated communities together into a single category. A number of the results we obtained, and inferences drawn, may therefore only be relevant or applicable to a certain type of gated community (ie, either an enclosed neighborhood or a security village). Finally, we examined the effect of gated communities on the extent of burglary in a period of three years post gating. It is possible that gated communities provide a longer term inhibitory effect on burglary although we believe that a three year period post-gating is adequate enough to test at least the short term effects of gating on crimes of this nature. Future research could aim to investigate the longer term effects of gating on the extent of burglary. Measuring the effect of gated communities on the spatial-temporal density of other types of crimes would also be of value.

\section{Conclusion}

The twomain aims of this research were to investigate the effect that gated communities have on burglary, and to determine which physical characteristics of gated communities are associated with high and low burglary.In accomplishing these goals this research makes several important contributions to the existing literature on gated communities. First, this study demonstrates that gating does not necessarily prevent crimes such as burglary but can in some instances even attract criminal behaviour, both during the day and during the night. While it may be that this findingis context-specific, the fact that this study is the first of its kind in South Africa, and indeed anywhere, makes it highly significant.Second, the study has demonstrated that certain physical characteristics of gated communities can be effective in 
deterring (and enabling) criminal activity. Specifically, the size of gated communities and the number of land parcels contained within them are of most importance. More research is needed to determine if these findings are generalizable to other countries. We believe that the results presented here are sufficiently valuable to merit further investigation; and that they provide an important empirical platform for future research investigating the association between crime and gated communities.

\section{References}

AfriGIS(2011).AfriGIS data catalogue.Retrieved November 14, 2012, from www.afrigis.co.za/wp.../AfriGISDataCatalogue_February2012.pdf

Altbeker, A. (2005). Positive trends: 2004/05 crime statistics.SA Crime Quarterly, 14,1-10

Atkinson, R.,Blandy, S., Flint, J. \& Lister, D.(2004).Gated Communities in England.(London:Office of the Deputy Prime Minister)

Atlas, R. \&LeBlanc, W. G.(1994).The impact on crime of street closures and barricades: a Florida case study.Security Journal,5, 140-145.

Berg, J. \&Schärf, W.(2004).Crime statistics in South Africa 1994-2003.South African Journal of Criminal Justice,17, 57-78.

Blakely,E.J. \& Snyder, M. G.(1997).Fortress America: Gated Communities in the United States. (Washington, DC: Brookings Institution Press)

Blakely, E. J. \&Snyder, M. G.(1998).Separate places: crime and security in gated communities. (In M. Felson, \&R. B.Peiser (Eds.),Reducing Crime through Real Estate Development and Management(pp. 53-70). Washington, DC: Urban Land Institute) 
Blandy, S.\& Parsons, D.(2002, July).Gated communities and urban planning: globalisation or national policy.(Paper presented at the $17^{\text {th }}$ IAPS Conference, Coruna, Spain)

Breetzke, G. D.(2006).Geographical Information Systems (GIS) and policing in South Africa: a review.Policing: An International Journal of Policing Strategies and Management.29, 723-740

Breetzke, G. D. \&Horn, A. C.(2008).Key requirements in the development of a spatialecological theory of crime in South Africa.ActaCriminologica,21, 123-143

Breetzke, G. D.(2012). The effect of altitude and slope on the spatial patterning of burglary.Applied Geography,34, 66-75

Bremner, L. (1998).Crime and the emerging landscape of post-apartheid Johannesburg.(InJuden,H.\&I. Vladislavic (Eds.),Blank_—: Architecture, Apartheid and After.(pp. 48-63). Cape Town:David Philip)

Byrne, J. M. \& Sampson, R. J.(1986). Key issues in the social ecology of crim. (In J. M. Byrne,\&R. J. Sampson (Eds.),The Social Ecology of Crime.(pp. 1-22). New York: Springer Verlag)

Caldeira, T. P. R.(2000).City of Walls: Crime, Segregation and Citizenship in Sao Paulo. (Berkeley, CA: University of California Press)

Coetzer, C.(2001, September).Crime prevention in neighbourhoods.(Paper presented at the Annual CPTED Association Conference, Sydney)

Coupe, T.\&Blake, L.(2006).Daylight and darkness targeting strategies and the risks of being seen at residential burglaries.Criminology,44, 431-464

Davis, M.(1992). Fortress Los Angeles: The militarization of urban space.(InM. Sorkin (Ed.),Variations on a Theme Park: Scenes from the New American City and the End of Public Space(pp. 154-180). New York:Hill and Wang) 
Dillon, D.(1994). Fortress America: more and more of us living behind locked gates.Planning, 60, 2-8.

Dixon, J. \&Lysner, P.(2004).Urban innovation or fortification?Planning Quarterley, March, $9-12$

Durington, M.(2009).Suburban fear, media and gated communities in Durban, South Africa.Home Cultures, 6, 71-88

Fowler, F. J. Jr.\&Mangione, T. W.(1986).A three-pronged effort to reduce crime and fear of crime: the Hartford experiment.(InD. P. Rosenbaum (Ed.),Community Crime Prevention:Does it Work?(pp. 87-108). Newbury Park, CA:Sage)

Giglia, A.(2008).Gated communities in Mexico City.Home Cultures, 5, 65-84

Glasze, G. \&Alkhayyal, A.(2002).Gated housing estates in the Arab world: case studies in Lebanon and Riyadh, Saudi Arabia.Environment and Planning B: Planning and Design,29, 321-336

Groff, E. \& McCord, E. S.(2011).The role of neighborhood parks as crime generators.Security Journal,25, 1-24

Helsley, R.\&Strange, W. C.(1999).Gated communities and the economic geography of crime.Journal of Urban Economics,46,80-105

Hough, M.(2003). Crime in South Africa: Is it a threat to national security?(InM. Hough,\& A. Du Plessis (Eds.),Combating Crime in South Africa: Contemporary Perspectives(pp. 188-205). Pretoria: Institute for Strategic Studies)

Human Sciences Research Council (2006).South African Social Attitudes Survey 2006. (Pretoria: HSRC Press) 
Jürgens, U. \&Gnad, M.(2002).Gated communities in South Africa - experiences from Johannesburg.Environment and Planning B: Planning and Design,29,337-353

Kim, S. Y.(2006)The Gated Community: Residents' Crime Experience andPerception of Safety Behind Gates and Fences in the Urban Area. PhD thesis, Texas A\&M University

Landman, K.(2000).An Overview of Enclosed Neighbourhoods in South Africa.(Pretoria: CSIR Publication)

Landman, K.(2004).Gated Communities in South Africa: Comparison of Four Case Studies in Gauteng.(Pretoria: CSIR Publication)

Landman, K. \&Schönteich, M.(2002).Urban fortresses: gated communities as a reaction to crime.The African Security Review, 11, 71-85

Lee,M. \&Herborn, P.(2003). The role of place management in crime prevention: some reflections on governmentality and government strategies.Current Issues in Criminal Justice, 15, 26-39

Leisch, H.(2000).Gated communities in Indonesia.Cities, 19,341-350

Lipman, A. \& Harris, H.(1999).Fortress Johannesburg.Environment andPlanning B: Planning and Design,26, 727-740

Lemanski, C.(2004).A new apartheid?The spatial implications of fear of crime in Cape Town, South Africa.Environment and Urbanization,16, 101-112

Lévay, M.(2000). Social changes and rising crime rates: the case of central and eastern Europe. European Journal of Crime, Criminal Law and Criminal Justice, 8, 35-50

Low, S. M.(2001).The edge and the center: gated communities and the discourse of urban fear. American Anthropologist, 103, 45-58 
Luymes, D.(1997).The fortification of suburbia: investigating the rise of enclave communities.Landscape and Urban Planning,39, 187-203

Lynch, M.(2001).From the punitive city to the gated community: security and segregation across the social and penal landscape.University of Miami Law Review,56, 89-111

Malan, M.(1996).Peacebuilding in post-conflict South Africa: the need for a comprehensive demobilisation and remobilisation programme.African Security Review, 5, 28-50

Marcuse, P.(1997).Walls of fear and walls of support.(InN. Ellin (Ed.), Architecture of Fear(pp. 101-114).New York: Princeton Architectural Press

McCord, E. S. \&Ratcliffe, J. H.(2009). Intensity value analysis and the criminogenic effects of land use features on local crime patterns.Crime Patterns and Analysis, 2, 368-388

McDowall, D. \&Loftin, C.(1992).Comparing the UCR and NCS over time.Criminology30, $125-132$

Miao, P.(2010). Deserted streets in a jammed town: the gated community in Chinese cities and its solution. Journal of Urban Design, 8, 45-66

Mills, G.(1991). Walls and warriors: Speculations on the relationship of urban design and crime in the new South Africa,Urban Forum,2,89-93.

Mistry, D. (2004)Falling crime, rising fear: 2003 National Victims of Crime Survey.South Africa Crime Quarterly,8, pp. 17-24.

Mohit, M. A. andAbdulla, A.(2011)Residents' crime and safety perceptions in gated and nongated low middle income communities in Kuala Lumpur, Malaysia.Journal of Architecture, Planning and Construction Management, 1, 71-94

Naudé, B.(2003). The effectiveness of public road closures in suburban areas as a crime reduction measure. Security Focus, 21, 34-36 
Newman, O.(1972).Defensible Space: Crime Prevention through Environmental Design.(New York: Macmillan)

Newman, O.(1980).Community of Interest.(Garden City, NY: Anchor Press)

Paynich,R. \&Hill, B.(2010).Fundamentals of Crime Mapping.(Sudbury, MA:Jones \&Bartlett Publishers)

Plaut, P. O.(2011).The characteristics and tradeoffs of households choosing to live in gated communities. Environment and Planning B: Planning and Design,38, 757-775

Pridemore, W. A.(2007).Change and stability in the characteristics of homicide victims, offenders and incidents during rapid social change.British Journal of Criminology,47, $331-345$

Roitman, S. \&Giglio, M. A.(2010). Latin American gated communities: the latest symbol of historical social segregation.(InS. Baganeen, \& O. Uduku (Eds.), Gated Communities: Social Sustainability in Contemporary and Historical Gated Developments(pp. 6378). (London:Earthscan Publications)

Shaw, M.(1997). A safer cities and towns programme for South Africa.(In ISS Monograph No. 11 Towards Safer Cities: The South African Debate on Options for Urban Safety. Pretoria:Institute for Security Studies)

Shaw, M.(2000).Crime and Policing in transitions: Comparative Perspectives.Johannesburg: SAIIA Publication)

Shaw, M.(2002).Democracy's disorder?Crime, police and citizen responses in transitional societies.(Johannesburg: SAIIA Publication)

Sheinbaum, D.(2008).Gated communities in Mexico City: an historical perspective.Urban Design International, 13,241-252 
South African Police Services (SAPS) (2011).2010/11 Crime Statistics. RetreivedNovember 14,2012 , from

http://www.saps.gov.za/saps_profile/strategic_framework/annual_report/index.htm

Uduku, O.(2010). Lagos: 'urban gating' as default condition.(InS. Bagaeen, \&O. Uduku(Eds.),Gated Communities: Social Sustainability in Contemporary and Historical Gated Developments(pp. 39-48). London:Earthscan)

Vesselinov, E.(2008). Members only: gated communities and residential segregation in the metropolitan United States.Sociological Forum,23, 536-555

Vilalta, C. J.(2011).Fear of crime in gated communities and apartment buildings: a comparison of housing types and a test of theories.Journal of Housing and the Built Environment,26, 107-121.

Vrodljak, M.(2002)Place and the Politics of Subjectivity. PhD Thesis, University of the Witwatersrand

Wilson-Doenges, G.(2000). An exploration of sense of community and fear of crime in gatedcommunities.Environment and Behavior,32, 597-611 